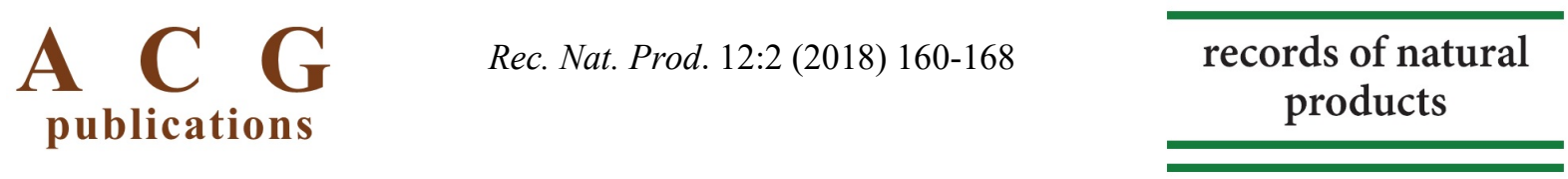

\title{
Chemical Constituents and Antibacterial Activity of Essential Oils from Flowers and Stems of Ageratum conyzoides from Ivory Coast
}

\author{
Bi Koffi François P. Kouame ${ }^{\odot * 1,2,3}$, Daouda Toure ${ }^{\oplus 3,4}$, Landry Kablan ${ }^{\oplus 1,3}$, \\ Gustave Bedi $^{\oplus 1}$, Illa Tea ${ }^{\oplus 2}$, Richard Robins ${ }^{\oplus 2}$, Jean Claude Chalchat ${ }^{\oplus 5}$ and \\ Felix Tonzibo ${ }^{\oplus}$ \\ ${ }^{1}$ LCOSN, UFR SSMT, 08 BP 582 Abidjan 08, Université F. H. B. Abidjan, Côte d'Ivoire \\ ${ }^{2}$ EBSI Group, CEISAM, University of Nantes-CNRS UMR6230, BP 92208, 44322 Nantes, France \\ ${ }^{3}$ UFR des Sciences Biologiques, Université P. G. C. Korhogo, BP 1328 Korhogo, Côte d'Ivoire \\ ${ }^{4}$ Laboratoire de Bactériologie-Virologie, Institut Pasteur, 01 BP 490 Abidjan 01, Côte d'Ivoire \\ ${ }^{5}$ Laboratoire de chimie des Hétérocycles et des Glucides Chimie des huiles essentielles, Les Cezeaux, 63177, \\ Aubière France \\ (Received June 19, 2017; Revised September 13, 2017; Accepted September 14, 2017)
}

\begin{abstract}
The essential oils (EOs) obtained by hydro-distillation of flowers and stems of Ageratum conyzoides L. (Asteraceae) growing in Ivory Coast were investigated. The oils were analyzed and characterized by GC and GC-MS. Analyses of the EOs led to the identification and quantification of 48 constituents in the flower oil and 44 from the stem oil, respectively. Characterization of the EOs revealed the predominance of 6-demethoxyageratochromene or precocene I (flower: $58.8 \%$, stem: $76.5 \%$ ) and the sesquiterpene $\beta$-caryophyllene (flower: $15.2 \%$, stem: $8.1 \%$ ). Six of the identified compounds $\beta$-copaene, hexanal, trans-cadina-1(6),4-diene, $\alpha$-calacorene, caryophylla-4(12), $8(13)$-diene-5- $\beta$ ol and 1,10-di-epi-cubenol are reported for the first time as constituents of $A$. conyzoides. Comparative analysis with data from Nigeria, Pakistan, Fiji and Brazil is reported. The antibacterial activity of EOs from of $A$. conyzoides was tested against seven bacteria. The inhibition zones and minimum inhibitory concentration (MIC) for bacteria strains which were sensitive to A. conyzoides EOs were in the range of 6.7 to $12.7 \mathrm{~mm}$ and 64 to $256 \mu \mathrm{g} / \mathrm{mL}$, respectively. The EOs showed moderate activity against Staphylococcus aureus and Enterococcus faecalis.
\end{abstract}

Keywords: Ageratum conyzoides; essential oils; flowers; stems; precocene I; antibacterial activity; Ivory Coast. (C) 2018 ACG Publication. All rights reserved.

\section{Introduction}

Ageratum conyzoides L. belongs to the family Asteraceae, tribe Eupatoriae. The genus Ageratum consists of approximately 30 species but only a few species have been phytochemically investigated [1], $A$. conyzoides is a tropical plant that is very common in West Africa as well as in some parts of Asia and South America. It is an annual branching herb which grows to approximately $1 \mathrm{~m}$ in height [2]. This plant is known mainly for its therapeutic qualities and has traditionally been used in various parts of Africa, Asia and South America for curing a variety of diseases. In West Africa, in addition to its popular use for skin diseases and wound healing [3, 4], A. conyzoides is also employed as an antimalarial agent [5, 6]. Additionally, in Ivory Coast, A. conyzoides is used against gastrointestinal pain [7], in the treatment of epilepsy, measles, eye diseases, headache, as an anthelminthic, an antidiabetic, and to facilitate childbirth [8-13]. A. conyzoides found in India, China, Brazil and Colombia has been used in folk medicine for the treatment of several diseases such as boils, eczema, diarrhea, leprosy, metrorrhagia, dermatitis, fever and inflammation. It has also been used as anti-hemorrhagic, analgesic, diuretic, antipyretic, insecticide and to treat rheumatism [14-

* Corresponding author: E-Mail: bikoffikouame@gmail.com; Phone:+225 43236095

The article was published by ACG Publications www.acgpubs.org/RNP (C) March-April 2018, EISSN:1307-6167 DOI: http://doi.org/10.25135/rnp.22.17.06.040 
18]. In Central and Southern Africa (Cameroon, Congo and Kenya), A. conyzoides is used in traditional medicine to treat pneumonia [19], pain [20], for its anti-asthmatic, antispasmodic, haemostatic, emetic, analgesic and anesthetic properties, as well as for uterine issues [21-23].

Widespread traditional use of this plant in the cure of several diseases has led to the investigation of the biological activities of its extracts. Assays using whole plant hexane extracts in Colombia, or petroleum ether and acetone extracts of leaves in India, have demonstrated insecticidal activity against $M u s c a$ domestica and Culex quinquefasciatus larvae $[15,24,25]$. Similar results were observed for Anopheles stephensi larvae in others assays, confirming the anti-juvenile hormone potential of A. conyzoides [26, 27]. In Cameroon, Nigeria, Sudan, Kenya and Ivory Coast, the methanol, ethanol, chloroform, petroleum ether and aqueous extracts of the plant have shown the following properties: cicatrizing [14, 28], antiurolithic [29], antioxidant [30], antidiabetic [8], antibacterial [19, 31], haemostatic [32], antispasmodic [33], antimalarial and antidiarrheal $[5,6,34]$.

A large number of pharmacological activities have been attributed to the essential oil (EO) of $A$. conyzoides [17]. The plant produces a volatile oil with a strong odor for which chemical analysis in different countries has shown significant variation in chemical composition. In the west of India, the EO obtained from all part of $A$. conyzoides has shown a dominance of precocene I $(52.2 \%)$ and caryophyllene $(26.2 \%)$. This EO has demonstrated fungicidal activity by inhibiting the growth of Aspergillus parasiticus and the production of aflatoxin. The strongest antibacterial activity was observed against the bacteria Staphylococcus aureus and Bacillus subtilis [35]. The main components of the EOs of flowers and a combination of leaves plus stems of $A$. conyzoides from Pakistan were $\beta$-caryophyllene (14.4\% and 17.0\%), 6-demethoxyageratochromene $(30.3 \%$ and $26.6 \%)$ and ageratochromene $(34.9 \%$ and $36.9 \%)$, respectively [36]. Eos extracted from leaves of $A$. conyzoides collected in Ibiúna, Ribeirão Pires and Campinas in the São Paulo state, southeastern Brazil have shown some differences in chemical constitution [37]. There is also a significant difference between the amounts of the major compounds (precocene I and II) in the EOs of leaves and aerial parts of the plants growing in Ibiuna [38]. This indicates the chemical composition of the EO may vary depending on the part of the plant studied. A similar observation has been made for volatiles oils extracted from the different parts (inflorescence, leaf, stem, root) of the plant collected in Santarém Novo (State of Pará, northern Brazil) [39]. Chemical compositions of the EOs extracted from the leaves of $A$. conyzoides acclimatized in the western zone of Africa display a similar pattern. The leaves of Ghanaian plants contain $80.3 \%$ of precocene I [40], while those from Burkina-Faso, Benin, Lagos and Ibadan (Nigeria) respectively contain $86.0 \%$ [41], 85.6\%, 63.1\% [42] and 82.2\% [43]. The EO exhibited remarkable insecticidal activity-against the cowpea weevil, Callosobruchus maculatus F. [44]. Work on EOs extracted from the leaves of $A$. conyzoides acclimatized in Ivory Coast showed a different chemical composition with only $46.5 \%$ of precocene I [41]. There is no comparative information on the EOs extracted from the flowers and stems of plants from Ivory Coast and elsewhere in Africa.

From the literature review it is evident that: (i) geographical variations have a major quantitative and/or qualitative impact on the chemical constituents of EOs; (ii) the chemical composition of the EO may vary depending on the part of the plant studied; (iii) there is little research on the antibacterial activity of $A$. conyzoides EOs. This work presents the chemical compositions and antibacterial activities of the EOs extracted from the stems and flowers of the same A. conyzoides plants originating from Ivory Coast.

\section{Materials and Methods}

\subsection{Plant Material}

Flowers and stems of Ageratum conyzoides were collected at 8 am in Bobia village in the west of Ivory Coast. Plant material was identified by Professor Ake Assi in the National Floristic Center of the University of Felix Houphouët Boigny, Cocody-Abidjan, Department of Botany, Ivory Coast where voucher specimens were deposited (Herbarium Voucher Number: CNF-14229).

\subsection{Isolation of the Essential Oil}

The EOs were isolated from fresh flowers and stems by hydrodistillation using a Clevenger-type apparatus. The obtained oils were dried over anhydrous sodium sulfate and, after filtration, stored in a sealed sample tube at $0^{\circ} \mathrm{C}$ until GC and GC-MS analysis. 


\subsection{Chemical Analyses of the Essential Oil}

EO composition was investigated first by Gas Chromatography (GC) with a flame ionization detector (FID) and then by GC coupled with a Mass Spectrometer (GC-MS).

\subsubsection{GC-FID Conditions}

GC analysis was carried out using a Delsi DI 200 instrument equipped with a FID and a DB5 column $(25 \mathrm{~m} \times 0.25 \mathrm{~mm}$, df: $0.25 \mu \mathrm{m})$ with a split flow rate of $60 \mathrm{~mL} / \mathrm{min}$. Nitrogen was used as carrier gas; temperature programming was $5 \mathrm{~min}$ at $50^{\circ} \mathrm{C}$ and $30^{\circ} \mathrm{C} / \mathrm{min}$ up to $220^{\circ} \mathrm{C}$, injector and detector temperatures were respectively set to $220^{\circ} \mathrm{C}$ and $250^{\circ} \mathrm{C}$.

\subsubsection{GC-MS Conditions}

GC-MS analysis was performed using a Hewlett-Packard gas Chromatograph Model 6890 coupled to a Hewlett-Packard MS Model 6890 equipped with an HP5 column (30 m x $0.25 \mathrm{~mm}$, df: $0.25 \mu \mathrm{m})$. Initial oven temperature was maintained at $50^{\circ} \mathrm{C}$ for $5 \mathrm{~min}$ and then programmed at $50{ }^{\circ} \mathrm{C} / \mathrm{min}$ to $300{ }^{\circ} \mathrm{C}$ (held 50 $\mathrm{min})$. The carrier gas was helium $(1.0 \mathrm{~mL} / \mathrm{min})$; a split injection with a split ratio $1: 10$ was chosen. Injector and detector temperatures were respectively set to $250^{\circ} \mathrm{C}$ and $320^{\circ} \mathrm{C}$. The electron multiplier was set at 2200 $\mathrm{V}$ with an applied electron ionization voltage of $70 \mathrm{eV}$, with the ion source temperature at $230^{\circ} \mathrm{C}$. Mass spectral data were acquired in the scan mode in the $\mathrm{m} / \mathrm{z}$ range of 33-450. Identification of compounds was carried out by calculating Retention Indices (RI) or Koväts Indices (KI) and comparing mass spectra with those in data banks, i.e. Adams [45] or Mc Lafferty and Stauffer [46]. For quantification purposes, relative area percentages obtained by field ionization detection (FID) were used.

\subsection{Bacterial strains}

Pure bacterial strains were obtained from the Institut Pasteur de Côte d'Ivoire (IPCI) and were either from the ATCC or clinical isolates. Bacteria strains were cultured overnight at $37^{\circ} \mathrm{C}$ in nutrient agar (NA, Oxoid). EOs were tested against the following microorganisms:

Gram-positive: Enterococcus faecalis USSURMI 469C/13, Staphylococcus aureus USSURMI 524C/13, Staphylococcus aureus ATCC 25923.

Gram-negative: Klebsiella pneumonia USSURMI 444C/13, Shigella sp. USSURMI 434C/13, Escherichia coli ATCC 25922, Citrobacter koseri USSURMI 745C/13, Enterobacter aerogenes USSURMI $746 \mathrm{C} / 13$.

\subsection{In vitro Antimicrobial Evaluation}

The in vitro antimicrobial activity of EOs was evaluated by the disc diffusion method using MuellerHinton Agar with determination of inhibition zones (IZ) according to the Committee of Clinical Laboratory Standards [47]. Freshly-grown microbial suspensions in Mueller-Hinton broth were standardized to a cell density of $1.5 \times 10^{8}$ (McFarland 0.5 ). In the disc sensitivity test, three different concentrations of the EOs were prepared by dissolving at $10 \%(\mathrm{v} / \mathrm{v})$ in dimethyl sulfoxide (DMSO). Discs of $6 \mathrm{~mm}$ diameter (BioRad) were sterilized at $121^{\circ} \mathrm{C}$ for $15 \mathrm{~min}$. An aliquot $(20 \mu \mathrm{L})$ of $\mathrm{EO}$ solution was applied to a disc and allowed to dry. After 18 to $24 \mathrm{~h}$ of incubation at $37^{\circ} \mathrm{C}$, the diameters of the growth inhibition zones were measured. The results are reported as mean \pm standard deviation (SD) for three repeats. Gentamicin $(30 \mu \mathrm{g} / \mathrm{disc})$ and DMSO $(10 \%)$ were used as positive and negative control, respectively. Gentamicin standard was purchased from Sigma-Aldrich.

\subsection{Determination of Minimum Inhibitory Concentration}

For minimum inhibitory concentration (MIC), a micro broth dilution method in broth media MuellerHinton (Difco) susceptibility assay was used. In these experiments, EO dissolved in Tween 80 (Merck, 
Germany) was first diluted to the highest concentration at the concentration $10 \%(\mathrm{v} / \mathrm{v})$ in order to enhance EO solubility. Geometric dilutions ranging from 0.5 to $1024 \mu \mathrm{g} / \mathrm{mL}$ of EOs were prepared in 96-well microtiter plates, the volume being $100 \mu \mathrm{L}$. Bismaleimidohexane $(90 \mu \mathrm{L})$ was added. As a final step, $10 \mu \mathrm{L}$ of $1 \times 10^{6} \mathrm{UFC} / \mathrm{mL}$ (according to $0.5 \mathrm{McF}$ arland turbidity standards) of standardized microorganism suspensions were inoculated into each well. The test was performed in a volume of $200 \mu \mathrm{L}$ with concentrations of 0.25 to $512 \mu \mathrm{g} / \mathrm{mL}$. All tubes were incubated in air at $37^{\circ} \mathrm{C}$ for $24 \mathrm{~h}$ before being read. The same test was performed simultaneously for the grow control (Mueller-Hinton broth + test microorganism) and sterility control (Mueller-Hinton broth + test oil). The MIC is the lowest concentration of the sample that prevented visible growth. Microorganism growth was indicated by the turbidity and a pellet on the well bottom.

\section{Results and Discussion}

\subsection{Composition of Essential Oils}

The hydrodistillation of flowers and stems of A. conyzoides afforded EOs (yellow) with yields of $0.22 \%$ and $0.19 \%(\mathrm{v} / \mathrm{w})$, respectively. The yield of EOs of the flowers compared favorably with the yields from flower of $A$. conyzoides from Fiji [48] and Nigeria [49]. GC and GC-MS analysis of A. conyzoides flower EOs led to the identification and quantification of a total of 51 major components accounting for $95.9 \%$ of the total components present. Forty-four constituents representing 98.2\% were identified in EO from the stems (Table 1). Flower and stem oils of the plants from Ivory Coast were dominated by chromenes and sesquiterpene derivatives. The main components were 6-demethoxyageratochromene or precocene I (flower $58.8 \%$, stem $76.5 \%$ ) and $\beta$-caryophyllene (flower $15.2 \%$, stem $8.1 \%$ ). The EOs of the flowers and stems of $A$. conyzoides from Ivory Coast both showed a precocene I and $\beta$-caryophyllene chemotype. The amount of precocene I was lower in the flowers and higher in the stems. Oil from the stems contained the lowest amount of $\beta$-caryophyllene. Among the identified compounds, seven have not been reported previously in $A$. conyzoides. These are $\beta$-copaene (flowers $0.03 \%$, stems $0.02 \%$ ), hexanal (flowers $0.03 \%$, stems $0.03 \%$ ), trans-cadina- $1(6), 4$-diene (flowers $0.50 \%$, stems $0.11 \%$ ), $\alpha$-calacorene (flowers $0.02 \%$, stems $0.02 \%$ ), caryophylla-4(12),8(13)-diene-5- $\beta$-ol (flowers $0.29 \%$, stems $0.06 \%$ ), 1,10 -di-epi-cubenol (flowers $0.08 \%$, stems $0.04 \%$ ) and $(E)$-nerolidol (flowers $0.61 \%$, stems $0.29 \%$ ).

Although, studies on the comparative percentage composition of A. conyzoides EOs from different regions and different parts of the plant are well documented [36, 39, 48, 49], this is the first report for EOs of both flowers and stems of $A$. conyzoides $\mathrm{L}$. from Ivory Coast. Results presented in Table 2 indicate that, whilst the flower oils of $A$. conyzoides from Ivory Coast, Nigeria, western Fiji and northern Brazil have the same chemotype dominated by precocene I and $\beta$-caryophyllene, this chemotype is different from that obtained for flowers oils from Pakistan and eastern Fiji, which have precocene I, $\beta$-caryophyllene and precocene II as the main components. In addition, stems oils of the plants of Ivory Coast and northern Brazil have a chemotype with precocene I and $\beta$-caryophyllene. However, although precocene I and $\beta$ caryophyllene are present in all samples, their amounts vary from plant to plant. Quantitatively, whilst only a trace of precocene II is found in the EOs of Ivory Coast plants (flower: 0.12\%, stem: $0.06 \%$ ) and western Fiji (flower: $0.4 \%$ ), this component is completely absent in oils from Nigeria and northern Brazil. In contrast, the percentages of precocene II in the flower oils of Pakistan and eastern Fiji are substantial: $34.9 \%$ and 15.5\%, respectively.

The difference in chemical composition of EOs can be attributed to climatic variations specific to each location, which shows the importance of geo-ecological factors in the production of metabolites of the plant. 
Table 1. Chemical constituents of essential oil extracted from flowers or stems of Ageratum conyzoides

\begin{tabular}{|c|c|c|c|c|}
\hline \multirow{3}{*}{$\frac{\mathrm{N}^{\circ}}{1}$} & \multirow{3}{*}{$\begin{array}{c}\text { KI } \\
839\end{array}$} & \multirow{3}{*}{ Compound } & \multirow{2}{*}{\multicolumn{2}{|c|}{$\begin{array}{cc}\text { Flower } & \text { Stem } \\
\text { Content }(\%)\end{array}$}} \\
\hline & & & & \\
\hline & & & 0.03 & 0.03 \\
\hline 2 & 934 & $\alpha$-pinene & 0.07 & 0.21 \\
\hline 3 & 951 & camphene & 0.36 & 1.60 \\
\hline 4 & 979 & $\beta$-pinene & 0.04 & 0.17 \\
\hline 5 & 990 & myrcene & 0.05 & 0.05 \\
\hline 6 & 999 & $\delta$-2-carene & 0.30 & 0.91 \\
\hline 7 & 1007 & $\alpha$-phellandrene & nd & 0.03 \\
\hline 8 & 1030 & limonene & 0.13 & 0.47 \\
\hline 9 & 1086 & terpinolene & nd & 0.05 \\
\hline 10 & 1100 & linalool & 0.04 & nd \\
\hline 11 & 1113 & (E)-4,8-dimethyl-nona-1,3,7-triene & 0.37 & 0.38 \\
\hline 12 & 1175 & endo borneol & 0.03 & 0.08 \\
\hline 13 & 1231 & bornyl formate & 0.20 & 0.49 \\
\hline 14 & 1286 & bornyl acetate & 0.68 & 1.29 \\
\hline 15 & 1290 & thymol & 0.06 & 0.24 \\
\hline 16 & 1310 & 2-methoxy-4-vinylphenol & 0.10 & nd \\
\hline 17 & 1334 & $\delta$-elemene & 0.03 & nd \\
\hline 18 & 1349 & $\alpha$-cubebene & 0.07 & nd \\
\hline 19 & 1353 & $\alpha$-longipinene & 0.25 & 0.03 \\
\hline 20 & 1358 & eugenol & 0.04 & 0.04 \\
\hline 21 & 1379 & $\alpha$-copaene & 0.13 & 0.03 \\
\hline 22 & 1387 & $\beta$-bourbonene & 0.07 & nd \\
\hline 23 & 1390 & $\beta$-cubebene & 1.06 & 0.22 \\
\hline 24 & 1425 & $\beta$-caryophyllene & 15.20 & 8.06 \\
\hline 25 & 1430 & $\beta$-copaene & 0.03 & 0.02 \\
\hline 26 & 1435 & trans- $\alpha$-bergamotene & 0.22 & 0.08 \\
\hline 27 & 1442 & $(Z)$ - $\beta$-farnesene & 0.19 & 0.15 \\
\hline 28 & 1454 & $\alpha$-humulene & 1.68 & 1.43 \\
\hline 29 & 1460 & $(E)-\beta$-farnesene & 1.58 & 0.54 \\
\hline 30 & 1469 & 6-demethoxyageratochromene (precocene I) & 58.78 & 76.46 \\
\hline 31 & 1474 & trans-cadina-1(6),4-diene & 0.50 & 0.11 \\
\hline 32 & 1479 & $\gamma$-cadinene & 0.14 & 0.07 \\
\hline 33 & 1486 & germacrene-D & 2.84 & 0.93 \\
\hline 34 & 1496 & trans-muurola-4(14),5-diene & 0.89 & 0.21 \\
\hline 35 & 1499 & bicyclogermacrene & 1.65 & 0.87 \\
\hline 36 & 1504 & $\alpha$-muurolene & 0.08 & nd \\
\hline 37 & 1509 & $\beta$-bisabolene & 0.11 & 0.06 \\
\hline 38 & 1520 & $\gamma$-cadinene & 0.48 & 0.07 \\
\hline 39 & 1526 & $\beta$-sesquiphellandrene & 1.82 & 0.88 \\
\hline 40 & 1536 & trans-cadina-1,4-diene & 0.04 & nd \\
\hline 41 & 1545 & $\alpha$-calacorene & 0.02 & 0.02 \\
\hline 42 & 1561 & $(E)$-nerolidol & 0.61 & 0.29 \\
\hline 43 & 1581 & spathulenol & 0.22 & 0.07 \\
\hline 44 & 1587 & caryophyllene oxide & 0.73 & 0.35 \\
\hline 45 & 1599 & 6-acethyl-2,2-dimethylchroman & 0.08 & 0.04 \\
\hline 46 & 1609 & humulene-1,2-epoxide & 0.04 & nd \\
\hline 47 & 1615 & 1,10-di-epi-cubenol & 0.08 & 0.04 \\
\hline 48 & 1632 & 1 -épi-cubenol & 0.09 & nd \\
\hline 49 & 1642 & caryophylla-4(12),8(13)-diene-5- $\beta$-ol & 0.29 & 0.06 \\
\hline 50 & 1653 & desmethoxyencecalin & 1.61 & 0.22 \\
\hline 51 & 1660 & Ageratochromene (precocene II) & 0.12 & 0.06 \\
\hline 52 & 1676 & androencecalinol & 2.34 & 0.87 \\
\hline 53 & 2107 & phytol & 0.09 & 0.05 \\
\hline & & TOTAL & 95.85 & 98.15 \\
\hline
\end{tabular}

nd: not detected 
Table 2. Comparative percentage composition of flowers and stem oils of Ageratum conyzoides from Ivory Coast, Nigeria Pakistan, Fiji and Brazil.

\begin{tabular}{ccccccccc}
\hline & \multicolumn{2}{c}{ Ivory Coast } & $\begin{array}{c}\text { Nigeria } \\
{[\mathbf{4 9}]}\end{array}$ & $\begin{array}{c}\text { Pakistan Eastern Fiji } \\
{[\mathbf{3 6}]}\end{array}$ & \multicolumn{2}{c}{ Western } \\
{$[\mathbf{4 8}]$} & Fiji [48] & $\begin{array}{c}\text { Northern Brazil } \\
{[39]}\end{array}$ \\
\hline $\begin{array}{c}\text { Part of the plant } \\
\text { Main components (\%) }\end{array}$ & Flower & Stem & Flower & Flower & Flower & Flower & Flower & Stem \\
$\begin{array}{c}\text { 6-demethoxyageratochromene } \\
\text { (precocene I) }\end{array}$ & 58.78 & 76.46 & 57.20 & 30.30 & 38.30 & 53.80 & 55.50 & 71.60 \\
$\begin{array}{c}\beta \text {-Caryophyllene } \\
\text { Ageratochromene } \\
\text { (precocene II) }\end{array}$ & 15.20 & 8.06 & 18.50 & 14.35 & 20.50 & 18.70 & 19.40 & 12.80 \\
\hline
\end{tabular}

\subsection{Antibacterial Activity}

The antibacterial activities of the EOs extracted from the flowers and stems of $A$. conyzoides and evaluated on 3 gram-positive and 5 gram-negative bacteria are presented in Table 3 . The EOs exhibited a strong broad-spectrum antimicrobial activity against all these organisms when tested with the disk diffusion bioassay.

Table 3. Antibacterial activity of essential oils of $A$. conyzoides on some selected microorganisms

\begin{tabular}{|c|c|c|c|c|c|c|}
\hline \multirow{3}{*}{ Microorganisms } & \multirow{3}{*}{ Sources } & \multicolumn{3}{|c|}{ Zone of inhibition (mm) } & \multirow{2}{*}{\multicolumn{2}{|c|}{$\frac{\text { MIC }(\mu \mathrm{g} / \mathrm{mL})}{\text { Essential oil }}$}} \\
\hline & & \multicolumn{2}{|c|}{$\begin{array}{l}\text { Essential oils } \\
(20 \mu \mathrm{g} / \text { disc })\end{array}$} & \multirow{2}{*}{$\begin{array}{c}\text { Gentamici } \\
n \\
(30 \mu g / \text { disc })\end{array}$} & & \\
\hline & & Flower & Stem & & Flower & Stem \\
\hline Staphylococcus aureus & ATCC 25923 & $12.7 \pm 0.0$ & $12.0 \pm 0.7$ & $35.0 \pm 1.00$ & 64 & 64 \\
\hline Enterococcus faecalis & USSURMI 469C/13 & $8.3 \pm 1.4$ & $8.0 \pm 1.4$ & - & 256 & 256 \\
\hline Staphylococcus aureus & USSURMI 524C/13 & $9.7 \pm 0.0$ & $9.0 \pm 0.0$ & $63.7 \pm 0.6$ & 256 & 256 \\
\hline Klebsiella pneumoniae & USSURMI 444C/13 & $7.0 \pm 0.0$ & $6.7 \pm 0.0$ & $26.3 \pm 1.2$ & $>512$ & $>512$ \\
\hline Shigella $s p$ & USSURMI 434C/13 & $7.7 \pm 0.7$ & $7.7 \pm 0.0$ & $41.3 \pm 0.6$ & 512 & 512 \\
\hline Escherichia coli & ATCC 25922 & $7.7 \pm 0.7$ & $7.3 \pm 0.7$ & $22.3 \pm 1.2$ & 256 & 256 \\
\hline Citrobacter koseri & USSURMI 745C/13 & $7.3 \pm 0.7$ & $7.3 \pm 0.0$ & $27.3 \pm 0.6$ & 256 & 256 \\
\hline Enterobacter aerogenes & USSURMI 746C/13 & $6.7 \pm 0.0$ & $7.3 \pm 0.7$ & $22.3 \pm 1.2$ & 512 & 512 \\
\hline
\end{tabular}

USSURMI: Clinical isolate from Institut Pasteur de Côte d'Ivoire.

The inhibition zone (IZ) values for bacterial strains which were sensitive to EOs, were in range of 6.7 to $12.7 \mathrm{~mm}$. A. conyzoides EOs showed moderate antibacterial activity against strains of gram-positive bacteria Staphylococcus aureus and Enterococcus faecalis with zones of inhibition (IZ) between 8.3 and 12.7 $\mathrm{mm}$. The strongest antibacterial activity was observed against Staphylococcus aureus ATCC 25923. The bacterial strain Enterococcus faecalis 469C/13 obtained from clinical isolates was not sensitive to the antibiotic Gentamicin, while the EOs of the flowers and stems of A. conyzoides showed antibacterial activity against this bacterial strain (flower IZ $=8.3 \pm 1.4 \mathrm{~mm}$; Stem IZ $=8.0 \pm 1.4 \mathrm{~mm}$ ). In contrast, only low or negligible activity was observed against the gram negative bacteria Klebsiella pneumoniae, Shigella $s p$, Escherichia coli, Citrobacter koseri and Enterobacter aerogenes with IZs of 6.7 to $7.7 \mathrm{~mm}$. The bacteriostatic efficacy of $A$. conyzoides EOs estimated by minimum values of inhibitory concentration (MIC) was between 64 and $256 \mu \mathrm{g} / \mathrm{mL}$. For Klebsiella pneumoniae, Shigella sp and Enterobacter aerogenes strains, the MIC values are greater than or equal to $512 \mu \mathrm{g} / \mathrm{mL}$. The antibacterial activity of the EOs extracted from the flowers and stems of $A$. conyzoides observed in this study confirms the antimicrobial potential reported by Patil et al. [35] against other bacteria.

\section{Conclusions}

The essential oils of the flowers and stems of A. conyzoides collected in Ivory Coast both show a chemotype dominated by precocene I and $\beta$-caryophyllene. Amongst the 53 compounds identified, six are reported for the first time as constituents of $A$. conyzoides. Tests of antibacterial activity show that the EO from A. conyzoides has moderate antimicrobial activity against gram-positive bacteria but is less effective 
against gram-negative bacteria. The level of observed activity validates the use of the essential oils of this plant in traditional medicine for the treatment of infectious diseases. This study on the antibacterial activity of essential oils contributes to the search for new classes of antimicrobial agents needed due to the rapid increase in multidrug-resistant organisms [50].

\section{Acknowledgments}

The authors would like to thank Dr Kevin Bayle, from the Infrastructure and Environment Group, School of Engineering, the University of Glasgow, UK, for helpful comments on the manuscript.

\section{ORCID}

Bi Koffi François P. Kouame : 0000-0003-3959-7783

Daouda Toure: 0000-0002-0690-2502

Ahmond Landry C. Kablan: 0000-0001-8437-4023

Sahouo Gustave Bedi: 0000-0003-0177-7076

Illa Tea: $0000-0002-5369-7206$

Richard J. Robins: 0000-0002-5325-8983

Jean Claude Chalchat: 0000-0001-5292-0309

Zanahi Félix Tonzibo: 0000-0001-6813-6674

\section{References}

[1] H. M. Burkill (1985). The Useful Plants of West Tropical Africa. Vol. 1. Kew, England : Royal Botanic Gardens.

[2] M. K. Marks and A. C. Nwachuku (1986). Seed-bank characteristics in a group of tropical weeds, Weed Res. 26, p. 51-158.

[3] A. L. Okunade (1981). Ph.D Thesis. University of Ibadan, Nigeria. 84 p.

[4] A. L. Okunade (2002). Ageratum conyzoides L. (Asteraceae), Fitoterapia 73, 1-16.

[5] C. V. Ukwe, O. I. Ekwunife, E. A. Epueke, and C. M. Ubaka (2010). Antimalarial activity of Ageratum conyzoides in combination with chloroquine and artesunate, Asian Pac. J. Trop. Med. 3, 943-947.

[6] V. C. Ukwe, E. A. Epueke, O. I. Ekwunife, T. C. Okoye, G. C. Akudor, and C. M. Ubaka (2010). Antimalarial activity of aqueous extract and fractions of leaves of Ageratum conyzoides in mice infected with Plasmodium berghei, Int. J. Pharm. Sci. 2, 33-38.

[7] M. F. Bissangou and J. M. Ouamba (1997). Valorisation chimique de quelques espèces aromatiques et médicinales du congo (Ageratum conyzö̈des L, Chromolaena odorata King et Robinson, Hyptis suaveolens Poit et Lippia multiflora Moldenke), Pharm. Méd. Trad. Afr. 9, 70-84.

[8] K. S. Doh, K. N'guessan, and C. B. Aké (2013). Effect of Aqueous Extract of Ageratum conyzoides Leaves on the Glycaemia of Rabbits, The Pharma Innov. 2, 1-8.

[9] A. K. Kamanzi (2002). Plantes médicinales de Côte d'Ivoire : Investigations phytochimiques guidées des essais biologiques: Doctorat d'Etat ès-Sciences en biologie végétale. UFR Biosciences, Université de Cocody, Abidjan, $190 \mathrm{p}$.

[10] K. N'guessan (2008). Plantes médicinales et pratiques médicales traditionnelles chez les peuples Abbey et Krobou du Département d'Agboville (Côte-d'Ivoire): Thèse de Doctorat ès Sciences Naturelles, Université de Cocody-Abidjan, Côte d'Ivoire, 235 p.

[11] D. Ouattara (2006). Contribution à l'inventaire des plantes médicinales significatives utilisées dans la région de Divo (Sud forestier de la Côte d'Ivoire) et à la diagnose du poivrier de Guinée : Xylopia aethiopica (Dunal) A. Rich. (Annonaceae): Thèse de doctorat, Université de Cocody-Abidjan, Côte d'Ivoire, 184 p.

[12] F. H. Tra Bi (1997). Utilisation des plantes, par l'homme, dans les forêts classées du Haut-Sassandra et de Scio, en Côte-d'Ivoire. Thèse de Doctorat de 3ème Cycle. Université de Cocody-Abidjan, Côte d'Ivoire, 212 p.

[13] M. O. Vangah-Manda (1986). Contribution à la connaissance des plantes médicinales utilisées par les ethnies Akans de la région littorale de la Côte-d'Ivoire: Thèse de Doctorat de 3ème Cycle, Université Nationale de Côte-d'Ivoire, Abidjan, Côte d'Ivoire, 464 p.

[14] G. K. Dash and P. N. Murthy (2011). Wound healing effects of Ageratum conyzoides Linn, Int. J. Pharma Bio Sci. 2, 369-382. 
[15] A. G. González, Z. E. Aguiar, T. A. Grillo, J. G. Luis, A. Rivera, and J. Calle (1991). Methoxyflavones from Ageratum conyzoides, Phytochemistry 30, 1269-1271.

[16] X. C. Liu and Z. L. Liu (2014). Evaluation of larvicidal activity of the essential oil of Ageratum conyzoides L. aerial parts and its major constituents against Aedes albopictus, J. Entomol. Zool. Stud. 2, 345-350.

[17] A. C. Moura, E. L. Silva, M. C. Fraga, A. G. Wanderley, P. Afiatpour, and M. B. Maia (2005). Antiinflammatory and chronic toxicity study of the leaves of Ageratum conyzoides L. in rats, Phytomedicine 12, 138-142.

[18] L. A. Yamamoto, J. C. Soldera, J. A. S. Emim, R. O. Godinho, C. Souccar, and A. J. Lapa (1991). Pharmacological screening of Ageratum conyzoides L. (mentrasto), Memórias do Instituto Oswaldo Cruz. 86, 145-147.

[19] J. I. Durodola (1977). Antibacterial property of crude extracts from a herbal wound healing remedy-Ageratum conyzoides L., Planta Med. 32, 388-390.

[20] B. H. Bourobou (2004). Approches sur la contribution des médicaments traditionnels améliorés dans les soins de santé primaires : étude des cas, Pharm. Méd. Trad. Afr. 13, 35-48.

[21] H. Bouda, L. A. Tapondjou, D. A. Fontem, and M. Y. D. Gumedzoe (2001). Effect of essential oils from leaves of Ageratum conyzoides, Lantana camara and Chromolaena odorata on the mortality of Sitophilus zeamais (Coleoptera, curculionidae), J. Stored Prod. Res. 37, 103-109.

[22] E. Noumi and T. W. Dibakto (2000). Medicinal plants used for peptic ulcer in the Bangangte region, western Cameroon, Fitoterapia 71, 406-412.

[23] J. O. Kokwaro (1976). Medicinal plants of East Africa. Nairobi: East African Literature Bureau. 58 p.

[24] R. C. Saxena, O. P. Dixit, and P. Sukumaran (1992). Laboratory assessment of indigenous plant extracts for anti-juvenile hormone activity in Culex quinquefasciatus, Indian J. Med. Res. 95, 204-206.

[25] P. Sharma, L. Mohan, and C. N. Srivastava (2009). Anti-juvenile activity of Azadirachta indica extract on the development and morphometry of filaria vector, Culex quinquefasciatus (Diptera: Culicidae) Say, Parasitol. Res. 105, 1193-1203.

[26] A. Saxena and R. C. Saxena (1992). Effects of Ageratum conyzoides extract on the developmental stages of malaria vector, Anopheles stephensi (Diptera:Culicidae), J. Environm. Biol. 13, 207-209.

[27] R. C. Saxena, A. Saxena, and C. Singh (1994). Evaluation of growth disrupting activity of Ageratum conyzoides crude extract on Culex quinquefasciatus (Diptera: Culicidae), J. Env. Biol. 15, 67-74.

[28] O. W. Oladejo, I. O. Imosemi, F. C. Osuagwu, O. O. Oluwadara, A. Aiku, O. Adewoyin, O. E. Ekpo, O. O. Oyedele, and E. E. U. Akang (2003). Enhancement of cutaneous wound healing by methanolic extracts of Ageratum conyzoides in the wistar rat, Afr. J. Biomed. Res. 6, 27-31.

[29] M. A. Khan and D. Pradhan (2011). Antiurolithic activity of Ageratum conyzoides extract in rats, Pharmacologyonline 3, 953-958.

[30] A. Shirwaikar, P. M. Bhilegaonkar, S. Malini, and J. Sharath Kumar (2003). The gastroprotective activity of the ethanol extract of Ageratum conyzoides, J. Ethnopharmacol. 86, 117-121.

[31] A. Z. Almagboul, A. A. Farroq, and B. R. Tyagi (1985). Antimicrobial activity of certain sudanese plants used in folkloric medicine: Screening for antibacterial activity, part II, Fitoterapia. 56, 103-109.

[32] O. Bamidele, A. M. Akinnuga, M. M. C. Anyakudo, O. A. Ojo, G. B. Ojo, J. O. Olorunfemi, and O. P. Johnson (2010). Haemostatic effect of methanolic leaf extract of Ageratum conyzoides in albino rats, J. Med. Plant. Res. 4, 2075-2079.

[33] K. J. Achola, R. W. Munenge, and A. M. Mwaura (1994). Pharmacological properties of root and aerial part extracts of Ageratum conyzoides on isolated ileum and heart, Fitoterapia 65, 322-325.

[34] J. O. T. Emudainohwo, E. O. Erhirhie, and E. G. Moke (2015). Anti-diarrheal activity of the aqueous leaf extract of Ageratum conyzoides in wistar rats, J. Appl. Sci. Environ. Manage. 19, 169-175.

[35] R. P. Patil, M. S. Nimbalkar, U. U. Jadhav, V. V. Dawkar, and S. P. Govindwar (2010). Antiaflatoxigenic and antioxidant activity of an essential oil from Ageratum conyzoides L, J. Sci. Food Agric. 90, 608-614.

[36] M. Riaz, M. R. Khalid, and F. M. Chaudhary (1995). Essential oil composition of Pakistani Ageratum conyzoides L, J. Essent. Oil Res. 7, 551-553.

[37] R. H. Esper, E. Gonçalez, R. C. Felicio, and J. D. Felicio (2015). Fungicidal activity and constituents of Ageratum conyzoides essential oil from three regions in São Paulo state, Brazil, Arq. Inst. Biol. 2, 1-4.

[38] J. H. C. Nogueira, E. Gonçalez, S. R. Galleti, R. Facanali, M. O. M. Marques, and J. D. Felício (2010). Ageratum conyzoides essential oil as aflatoxin suppressor of Aspergillus flavus, Int. J. Food Microbiol. 137, 55-60.

[39] M. d. G. B. Zoghbi, M. d. N. d. C. Bastos, M. A. G. Jardim, and J. R. Trigo (2007). Volatiles of inflorescences, leaves, stems and roots of Ageratum conyzoides L. growing wild in the north of Brazil, J. Essent. Oil Bear. Pl. 10, 297-303.

[40] M. Mensah, K. Sarpong, K. H. C. Baser, and T. Özek (1993). The Essential oil of Ageratum conyzoides L. from Ghana, J. Essent. Oil Res. 5, 113-115.

[41] R. H. C. Nébié, R. T. Yaméogo, A. Bélanger, and F. S. Sib (2004). Composition chimique des huiles essentielles d'Ageratum conyzö̈des du Burkina Faso, C. R. Chim. 7, 1019-1022. 
[42] A. A. Kasali, P. Winterhalter, A. M. Adio, H. Knapp, and B. Bonnlander (2002). Chromenes in Ageratum conyzoides L, Flavour Fragr. J. 17, 247-250.

[43] O. Ekundayo, I. Laakso, and R. Hiltunen (1988). Essential oil of Ageratum conyzoides, Planta Med. 54, 55-57.

[44] A. A. Gbolade, O. A. Onayade, and B. A. Ayinde (1999). Insecticidal activity of Ageratum conyzoides L. volatile oil against Callosobruchus maculatus $\mathrm{F}$. in seed treatment and fumigation laboratory tests, Int. J. Trop. Insect. Sci. 19, 237-240.

[45] R. P. Adams (1995). Identification of Essential oil Components by Gas Chromatography/Mass Spectroscopy. . Illinois, USA: Allured Publishing Co.

[46] F. W. Mc Lafferty and D. B. Stauffer (1989). The Wiley NBS registry of mass spectral data. New York: 2ème Edition John Wiley and Sons.

[47] NCCLS National Committee for Clinical Laboratory Standards (1999). Performance standards for antimicrobial susceptibility testing. $6^{\text {th }}$ ed. Approved standards, M2-A6, Wayne, PA.

[48] W. G. L. Aalbersberg and Y. Singh (1991). Essential oil of fijian Ageratum conyzoides L., Flavour Frag. J. 6, 117-120.

[49] L. A. Usman, M. F. Zubair, N. O. Olawore, N. O. Muhammad, F. A. M'Civer, and R. O. Ismaeel (2013). Chemical constituents of flower essential oil of Ageratum conyzoides growing in Nigeria, Elixir Org. Chem. 54, 12463-12465.

[50] S. Gibbons, B. Ohlendorf, and I. Johnsen (2002). The genus Hypericum-a valuable resource of antiStaphylococcal leads, Fitoterapia 73, 300-304.

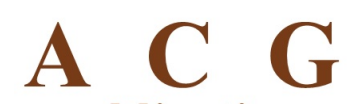

publications

(C) 2018 ACG Publications 